earth structure as well as provide minerals; (iii) there are large areas of potentially useful oil-bearing rocks in western Canada; (iv) no other country is in so interesting a position geophysically, since Canada includes the north magnetic pole, and extends to the north geographical pole, and nearly to the magnetic axis; a larger part of the maximum auroral belt crosses Canada than any other country; ( $v$ ) ionospheric studies for radio prediction have increased greatly during the War, and there are seven Canadian stations; the auroral belt will always produce peculiar effects; (vi) magnetic observations are lacking in northern Canada, where they are of value for navigation and of great interest near the magnetic pole.

More than a score of projects have already been initiated and further investigations are planned. One of the most fruitful subjects aided by the Committee has been the development of an airborne magnetometer. Fluxgate magnetometers were built by the National Research Council during the War; but these, it was known, would require extensive modifications before they could be adapted to airborne use. An early type was fitted to aeroplanes flying on Exercise Musk-Ox, in order to gain experience. In the United States, the Geological Survey had succeeded in adapting to geological use the magnetic aerial detector used in anti-submarine work, and it was thought that this instrument would be suitable for use in Canada. The National Research Council obtained three sets from the United States Navy and modified them so that they will be available to the Department of Mines and Resources for use in Canada during the summer of 1947.

Geophysical work will continue to be done and paid for by existing departments, companies and universities; but all this work will now be co-ordinated by the Associate Committee on Geodesy and Geophysics of the National Research Council. The Committee's work will not overlap that of the Geophysical Committee of the Geology Division of the Canadian Institute of Mining and Metallurgy, which deals with matters such as assessment laws, customs, and tax rates, methods of procedure and professional ethics.

Steps have been taken to hold open meetings of the Associate Committee on Geodesy and Geophysics, the first of which was in connection with the annual meeting of the Canadian Institute of Mining and Metallurgy at the National Research Buildings in Ottawa on 23 January 1947. The Committee proposes also to start publishing a bibliography on Canadian geophysics which will include reports on its activities.

\title{
THE PUBLIC SCHOOLS EXPLORING SOCIETY
}

The Public Schools Exploring Society was founded by the writer in 1932, to enable a number of British schoolboys each year to visit uninhabited country, to teach them to fend for themselves in the wilds, to widen their outlook and experience through having to overcome difficulties under primitive conditions, and to foster the spirit of adventure.

Although Public Schoolboys were selected to make a beginning, the term 
"Public School" is now widely interpreted; this year equal numbers of Public Schoolboys and Secondary Schoolboys make up a team of seventy-four boys. The assistant leaders are always commissioned officers of any of the three Services. The expeditions are of necessity made with scratch teams and it is a great advantage to have leaders with potentially similar ideas and training, the endeavour being to leave the school atmosphere behind.

This year's expedition (1947) will be the first since the war and the ninth since the Society's inception. There have been three to northern Lapland and five to the remoter parts of Newfoundland. Next year's expedition will probably be to the neighbourhood of the Quebec-Labrador borderland.

The exploration work of each expedition is taken seriously. The expedition goes straight.out to the wilds and returns direct, accepting no hospitality which might cut short the time available for exploration. The general scheme of each expedition is, after forming a base camp, to make a detailed map of as large an area as possible, using theodolite and plane table. The party employed on this work is chosen from those especially anxious to learn surveying. Other parties make compass traverses of about a week at a time, returning with data to tie up to the more detailed map. Each year a special feature is made of what is known as the "Long March" party. This is picked from volunteers (most of the expedition volunteer for it) selected for their physique and temperament. They do a fourteen days' compass traverse with the object of reaching a certain geographical point, not always gained, but acting as a stimulus to the best of their marching powers. With a ration weighing just under $2 \mathrm{lb}$. a day, equipment, light tents, etc., the pack of each member at the start weighs a little over $60 \mathrm{lb}$. One year a march of twenty days was made on the fourteen days' food, but that was an exceptional effort.

Special parties are formed for the study and collection of birds. Their notes and specimens are sent to the British Museum and have made valuable additions to the permanent collection of Newfoundland birds. The expeditions are fundamentally scientific, and those boys who are doing scientific work are so disposed that they are given the best opportunities for carrying it out. The "Bird Party", for example, is a separate unit, so that they can pick their terrain. They may want to spend some of their time on the tundra, some round the lakes and marshes for the wildfowl, and some in the denser forest country.

Before the second World War there was among the boys a good supply of specialists with a sound knowledge of ornithology. This year the expedition is not so well off. The same applies to botany and entomology. Young geologists are virtually non-existent. Surveying is by far the most popular science, and the R.E. officer will have a good team of boys with a fair elementary knowledge from which to form his party. Wireless is popular, but few, if any this year, bave more than a very elementary knowledge of the subject. Of guts and enthusiasm there are always plenty and to spare, and ample opportunity is provided for their exercise. The spirit of adventure is carefully fostered and some of the pack marches are really tough experiences.

The food consists of dehydrated rations scientifically calculated as to composition and calorific value, and there are no luxuries. 
The P.S.E.S. has been fortunate in the help so readily given by the Admiralty, the War Office and the Royal Geographical Society. All these have lent instruments. This year the entire survey equipment has been lent by the War Office and the entire radio equipment by the Admiralty, who have also, as in former years, arranged for their Whitehall Signal Station to exchange messages every night during the expedition with the base camp.

An important result of these expeditions has been to develop in many boys a desire to explore. In this way they have largely contributed to the ranks of the Oxford University Exploration Club, and it is hoped that those members who go up to Cambridge will get into touch with the Scott Polar Research Institute so that they may gain further encouragement to continue along the path on which they have been started by the P.S.E.S.

This article cannot be concluded without mention of a matter of much importance, not only to P.S.E.S. expeditions, but also to those who organise exploring expeditions anywhere. It is noticeable that in the majority of cases one or more doctors are taken who are not experienced in major surgery. It may well be asked how would a physician be able to deal with an operation for appendicitis or other acute abdominal condition during an expedition? The need then would be for a thoroughly experienced surgeon capable of operating under much more difficult conditions than he would find at home. It is running a risk to take only physicians. On this principle a surgical specialist has always been included in P.S.E.S. expeditions. The wisdom of this precaution became manifest in 1937 when a boy developed acute appendicitis and was operated on at ten o'clock at night under the forest trees by the light of electric torches held by assistants and with the mosquitoes cruelly biting the legs of the surgeon who was in shorts. The appendix was successfully removed and the boy was up in a fortnight, perfectly well.

G. MURRAY LEVICK

\section{WORK OF THE UNITED STATES COAST AND GEODETIC SURVEY IN ALASKA, 1944-46}

[From notes in the Annual Report of the Governor of Alaska to the Secretary of the Interior, 1945 , p. 8, and 1946, pp. 12-18.]

During 1944-45 surveys of the waters and coast of Alaska were continued. All work of this nature was restricted to strategic areas of vital importance to the military forces, where marine charts for safe navigation have not been available in previous years. Triangulation work continued, providing horizontal and vertical control for mapping and for other military and engineering projects. Four new nautical and thirty aeronautical charts of Alaska and the Aleutian Islands were constructed and reproduced for the use of the armed forces.

In 1946 the coast triangulation was extended along the Aleutian chain to Attu. It was also being extended across the Alaska Peninsula to Bristol Bay and the Bering Sea, in order to furnish horizontal control for mapping in the Bristol Bay area. More new charts were issued in 1946. Three new nautical charts were produced of the coastal waters of Alaska, including the Point 